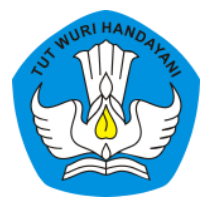

Page: 657-678

\title{
MENINGKATKAN KEMAMPUAN BERLARI, MELEMPAR, DAN MENANGKAP BOLA MELALUI PERMAINAN TIC TAC TOE BALL DI SEKOLAH DASAR
}

\author{
Irvan Nur Nugroho \\ Sekolah Dasar Negeri Karangtengah III, Yogyakarta, Indonesia \\ ContributorEmail: irvannurn@yahoo.com
}

Received: Feb 1, 2021

Accepted: Oct 6, 2021

Published: Nov 30, 2021

Article Url: $\underline{\text { https://ojsdikdas.kemdikbud.go.id/index.php/didaktika/article/view/230 }}$

\begin{abstract}
The learning outcomes of fourth grade students of SDN Karangtengah III Wonosari District, Gunungkidul Regency for the 2019/2020 academic year, the material for small ball games (kasti) including the basic movements of running, throwing, and catching the ball is still low. The results showed an increase in learning outcomes of the basic motion of running, throwing, and catching the ball after using the tic tac toe ball game. The result of the improvement is that through the tic tac toe ball game, students who get learning outcomes meet the minimum completeness criteria for grade IV is 77 , in the initial condition there are only six children or about $26 \%$. After the implementation of learning using the tic tac toe ball game, students who succeeded in achieving the minimum completeness criteria 77 increased to 21 students or about $91 \%$. The conclusion of this research is that the tic tac toe ball game can improve the learning outcomes of the basic movements of running, throwing, and catching the ball for fourth grade students of SDN Karangtengah III Wonosari in the 2019/2020 academic year.
\end{abstract}

Keywords: Tic Tac Toe Ball; Baseball; Learning Outcomes. 


\begin{abstract}
Abstrak
Hasil belajar siswa kelas IV SDN Karangtengah III Kecamatan Wonosari Kabupaten Gunungkidul Tahun Pelajaran 2019/2020 materi permainan bola kecil (kasti) meliputi gerak dasar berlari, melempar, dan menangkap bola masih rendah. Hasil peningkatan diperoleh bahwa melalui permainan tic tac toe ball, siswa yang memperoleh hasil belajar memenuhi nilai Kriteria Ketuntasan Minimal (KKM) untuk kelas IV adalah 77, pada kondisi awal hanya ada enam anak atau sekitar $26 \%$. Setelah diterapkan pembelajaran menggunakan permainan tic tac toe ball, siswa yang berhasil mencapai KKM 77 meningkat menjadi 21 siswa atau sekitar 91\%. Simpulan penelitian ini adalah permainan tic tac toe ball dapat meningkatkan hasil belajar gerak dasar berlari, melempar, dan menangkap bola siswa kelas IV SDN Karangtengah III Wonosari Tahun Pelajaran 2019/2020.
\end{abstract}

Kata Kunci: Kata Kunci; Kata Kunci; Kata Kunci; Kata Kunci; Kata Kunci

\title{
A. Pendahuluan
}

Pendidikan dasar merupakan landasan dasar pondasi untuk pendidikan ketingkat selanjutnya dan pembangunan nasional. Aset suatu bangsa tidak hanya terletak pada sumber daya alam yang banyak, akan tetapi terletak pada sumber daya manusia yang berkualitas dan mampu bersaing. Peningkatan sumber daya manusia sebagai modal dasar kekayaan yang kekal dan investasi untuk mencapai kemajuan bangsa. Peningkatan mutu pendidikan dasar berlaku secara menyeluruh, termasuk didalamnya adalah pendidikan jasmani. Banyak faktor yang memengaruhi keberhasilan pendidikan jasmani, salah satu faktor yang sangat menentukan keberhasilan pendidikan adalah kemampuan guru.

Pembinaan multilateral merupakan pengembangan anak melalui berbagai kegiatan jasmani menyeluruh yang meliputi berbagai gerak dasar umum dan gerak dasar olahraga (Lumintuarso, 2011). Pembinaan multilateral anak dapat mengembangkan potensi gerak yang lebih luas, sehingga memungkinkan anak dapat memiliki keterampilan gerak secara menyeluruh. Guru merupakan salah satu faktor penentu berhasil atau tidaknya suatu pendidikan di sekolah, sebab gurulah yang memberi bentuk, isi, dan arah kepada siswa didik sesuai dengan tujuan-tujuan pendidikan. Bermacam-macam kegiatan permainan disekolah dasar sangat berperan 
terhadap pengembangan fungsi-fungsi otot, syaraf, organ-organ tubuh, kejiwaan, dan kepribadian siswa. Kehidupan masyarakat manusia dituntut untuk berlaku jujur, bekerjasama, mematuhi hukum atau ketentuan-ketentuan lain yang telah disepakati bersama, maka dalam kegiatan bermain setiap pelakunya dituntut untuk memiliki kejujuran, dapat bekerjasama dengan baik, sportif, tunduk kepada peraturan permainan yang telah digariskan.

Pendidikan jasmani di sekolah merupakan bagian integral (tidak terpisahkan) dari pendidikan, karena pelaksanaan pendidikan jasmani di sekolah mempunyai tujuan untuk mencapai tujuan dari pendidikan nasional. Pendidikan jasmani di sekolah dasar meliputi dasar-dasar atletik, senam dan permainan. Pembelajaran pendidikan jasmani dengan permainan dapat menciptakan situasi yang interaktif antara guru dan siswa atau siswa dengan siswa yang akan melahirkan rasa senang atau gembira, saling membantu, saling berkompetisi secara sehat dan meningkatkan kreatifitas serta nalar siswa yang akan membawa perubahan sikap perilaku siswa dalam menuju ketingkat kedewasaan.

Manfaat pendidikan jasmani antara lain (a) Membantu siswa mengenali dunia, alam kehidupannya sendiri dan lingkungan dunia sekitarnya tempat dirinya berada; (b) Meningkatkan kesehatan jasmani, rohani dan sosial serta kegairahan hidup; (c) Meningkatkan kegemaran gerak, keluwesan gerakan dan kekayaan keterampilan gerak; (d) Memberikan bimbingan kearah penguasaan gerak sebagai orang dewasa, sebagai pribadi yang mantap dan kreatif; (e) Kesiapan menghadapi tugas pelajaran.

Perkembangan keterampilan gerak pada pendidikan dasar merupakan inti dari program pendidikan jasmani. Perkembangan keterampilan gerak bagi anak-anak sekolah dasar dapat diartikan sebagai perkembangan dan penghalusan macam-macam keterampilan gerak dasar dan keterampilan gerak yang berkaitan dengan olahraga. Keterampilan gerak ini dapat dikembangkan dan diperhalus sehingga dapat mencapai taraf tertentu yang akan memungkinkan anak tersebut mampu untuk melaksanakannya dengan tenaga yang hemat (efektif dan efisien) sesuai dengan keadaan lingkungannya. Jika keterampilan gerak anak tersebut sudah matang, secara otomatis kemampuan gerak dasar ini juga akan berkembang dengan 
sendirinya, selanjutnya kemampuan gerak dasar itu dapat mereka terapkan dalam bermacam-macam permainan.

Modifikasi model pembelajaran dalam Pendidikan Jasmani Olahraga dan Kesehatan (PJOK) sangat penting untuk diketahui dan dilaksanakan oleh para guru mata pelajaran PJOK. Modifikasi pembelajaran dapat membuat siswa memperoleh kepuasan dalam mengikuti pelajaran, meningkatkan kemungkinan keberhasilan dalam partisipasi, siswa dapat melakukan pola gerak secara benar (Lutan, 1988). Pendekatan modifikasi ini dimaksudkan agar materi yang ada didalam kurikulum dapat disajikan sesuai dengan tahapan perkembangan kognitif, afektif, dan psikomotor siswa. Guru merupakan kunci sukses dari segala kegiatan pembelajaran PJOK di sekolah, oleh karena itu kemampuan, kreatifitas, dan inovasi seorang guru mutlak diperlukan guna tercapainya keberhasilan pembelajaran tersebut.

Menurut (Slameto, 2010: 54) salah satu faktor eksternal yang dapat memengaruhi hasil belajar adalah penggunaan alat pembelajaran, agar hasil belajar gerak berlari, melempar dan menangkap bola optimal maka dalam pemilihan alat belajar harus sesuai dengan tujuan pembelajaran dan kompetensi yang akan dicapai, hal ini sesuai dengan pendapat (Munadi, 2012: 190). Pembelajaran gerak dasar berlari, melempar, dan menangkap bola idealnya menggunakan alat pembelajaran yang dapat digunakan untuk meningkatkan kemampuan siswa dalam melakukan gerak dasar berlari, melempar, dan menangkap bola. Idealnya alat pembelajaran tersebut dapat digunakan dalam permainan, sesuai karakteristik anak usia sekolah dasar. Sumantri \& Nana Sayodih dalam (Wardani, 2019) yaitu senang bermain, senang bergerak dan senang bekerja dalam kelompok. Alat pembelajaran juga harus aman, baik bagi pengguna maupun lingkungan sekitar. Penggunaan alat pembelajaran yang tepat dapat meningkatkan hasil belajar gerak dasar lempar tangkap. Salah satu permainan bola kecil yang sangat populer dan disukai anak Sekolah Dasar (SD) adalah permainan kasti. Permainan kasti ini merupakan permainan yang sangat digemari oleh anak-anak bahkan sampai orang dewasa, terbukti permainan kasti ini 
masih eksis dan dilombakan dalam perlombaan-perlombaan di kampung atau di desa, contohnya perlombaan memperingati Hari Ulang Tahun (HUT) Kemerdekaan Republik Indonesia (RI). Permainan kasti merupakan permainan beregu dengan jumlah permain tiap regu adalah 12 orang, yang dibagi menjadi dua regu, yaitu regu pemukul dan regu penjaga. Adapun teknik dasar dalam permainan kasti adalah memukul bola, melempar bola dan menangkap bola.

Sekolah Dasar Negeri (SDN) Karangtengah III berada di Kecamatan Wonosari Kabupaten Gunungkidul. Sekolah ini mempunyai gedung sekolah yang baik namun ruang bermain untuk siswa sangat sempit karena halaman sekolah yang dulunya untuk berolahraga sekarang dibangun gedung perpustakaan dan aula kegiatan siswa, didalam pembelajaran PJOK di SDN Karangtengah III salah satu materi pembelajarannya adalah permainan bola kasti, akan tetapi proses pembelajarannya belum dapat dilaksanakan secara optimal karena terbentur dengan permasalahan sarana dan prasarana yang digunakan dalam permainan tersebut sehingga dipandang perlu untuk memodifikasi sebagai upaya untuk meningkatkan hasil belajar siswa, dengan memodifikasi alat pembelajaran yang ada dalam permainan bola kasti.

Solusi untuk meningkatkan hasil belajar gerak dasar berlari, melempar dan menangkap bola adalah dengan pembelajaran menggunakan permainan tic tac toe ball, karena permainan ini menyenangkan dan mudah dimainkan oleh anak-anak usia sekolah dasar. Alat yang dibutuhkan dalam permainan ini sangat sederhana dan mudah didapatkan. Alat dalam permainan tic tac toe ball adalah bola plastik kresek, lapangan permainan tic tac toe ball, dan gawang lingkaran atau kolong. Bola dalam permainan tic tac toe ball terbuat dari plastik kresek dan kertas yang dibuat menjadi bentuk bola dan dimasukkan kedalam plastik kresek dan dibentuk menjadi bola kecil. Gawang lingkaran atau kolong terbuat dari selang air yang dibuat menjadi bentuk lingkaran atau kolong dengan cara disambung dengan ukuran atau diameter tertentu sesuai kebutuhan. Lapangan permainan tic tac toe ball terbuat dari kardus susu yang digabungkan dan dibuat kotak persegi dengan jumlah sembilan 
kotak. Alat yang digunakan dalam permainan tic tac toe ball sangat aman bagi siswa dan lingkungan sekitar karena terbuat dari bahan bekas atau daur ulang.

Permainan tic tac toe ball mengadopsi dan memodifikasi dari ide dasar permainan tiga jadi, yang prinsipnya pemain tercepat dapat menyusun tiga benda atau bola membentuk garis lurus secara horizontal, vertikal, dan diagonal adalah pemenangnya. Permainan tic tac toe ball ini menggunakan gerak dasar berlari, melempar, dan menangkap bola dalam pelaksanaannya. Permainan tic tac toe ball ini merupakan permainan sederhana, mudah, dan murah karena hanya memerlukan sedikit peralatan dan perlengkapan sehingga dapat dimainkan dimana saja meskipun dengan keterbatasan sarana dan prasarana. Permainan tic tac toe ball diharapkan dapat meningkatkan hasil belajar berlari, melempar dan menangkap bola dalam permainan kasti siswa kelas IV SDN Karangtengah III tahun pelajaran 2019/2020. Hal ini disebabkan permainan tic tac toe ball banyak melakukan gerakan berlari, melempar, dan menangkap bola sehingga dapat meningkatkan kemampuan siswa dalam melakukan gerak berlari, melempar, dan menangkap bola dengan kontrol yang baik, dengan demikian diharapkan hasil berlari, melempar dan menangkap bola semakin meningkat lebih baik. Permainan tic tac toe ball dapat menanamkan pendidikan karakter bagi anak yaitu sikap gotong royong (kerjasama), mandiri (kerja keras atau semangat) dan integritas (mematuhi aturan atau sportivitas) kepada siswa.

\section{B. Metode}

Berdasarkan tujuan yang telah diuraikan di atas, maka penelitian ini merupakan penelitian deskriptif kuantitatif yaitu menjelaskan fenomena yang ada dengan menggunakan angka-angka untuk mencandrakan karakteristik individu atau kelompok. Penelitian pengembangan ini peneliti pusatkan pada fokus peningkatan kemampuan berlari, melempar, dan menangkap bola dengan permainan tic tac toe ball di SDN Karangtengah III Wonosari Kabupaten Gunungkidul. 
Jenis penelitian ini adalah peningkatan bersiklus (penelitian tindakan). Penelitian tindakan ini difokuskan pada peningkatan kemampuan berlari, melempar, dan menangkap bola melalui permainan tic tac toe ball. Penelitian peningkatan dengan penelitian aksi (action research) dilakukan beberapa langkah. Menurut (Pidarta, 2012: 20-22) rancangan penelitian aksi dapat ditempuh dengan langkah-langkah sebagai berikut.

\section{Studi awal}

Semua fokus yang diteliti melalui survei di lapangan. Dilakukan identifikasi kemampuan awal siswa sebelum mendapatkan perlakuan, dengan tujuan untuk meningkatkan kemampuan berlari, melempar, dan menangkap bola melalui permainan tic tac toe ball di sekolah pada khususnya.

2. Pengembangan

a. Semua fokus dikembangkan sesuai dengan kriteria atau standar indikator yang telah ditentukan.

b. Siklus pengembangannya sebagai berikut.

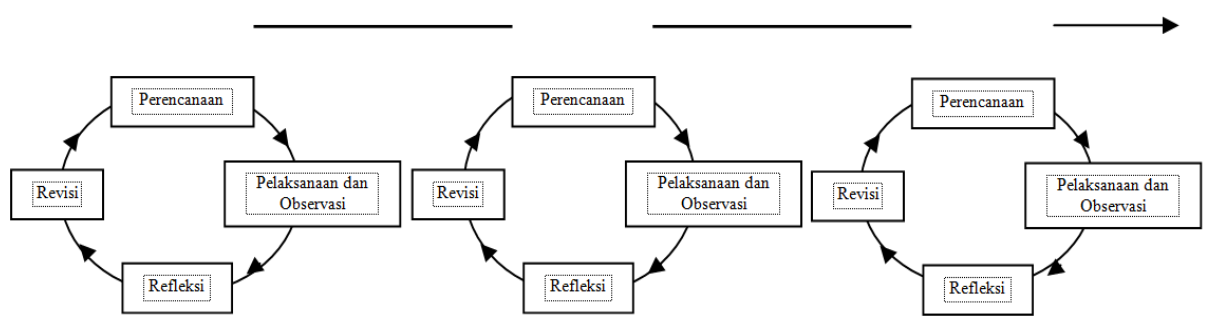

Gambar 1. Siklus Pengembangan

Siklus I

a. Semua fokus direncanakan cara-cara pengembangannya.

b. Pengembangan tersebut dilaksanakan dan diobservasi.

c. Hasil pengembangan direfleksi, artinya fokus mana yang berkembang dengan baik, mana yang baru setengah berkembang, dan mana yang sulit dikembangkan, dan sebagainya.

d. Bagi fokus-fokus yang belum berkembang dengan baik cara pengembangannya direvisi. Hasil revisi menjadi bahan perencanaan siklus II. 
Siklus II

Dilakukan dengan cara yang sama dengan siklus I, dengan perbaikan pada fokus-fokus yang belum berkembang pada siklus I.

Siklus III

Fokus-fokus yang belum berkembang pada siklus II, dikembangkan pada siklus III, dan siklus-siklus berikutnya. Demikian seterusnya, siklus pengembangan akan berhenti atau dihentikan kalau semua fokus yang dikembangkan sudah berkembang sesuai standar yang sudah ditentukan. Membandingkan hasil studi awal dengan kondisi akhir hasil peningkatan kemampuan berlari, melempar, dan menangkap bola melalui permainan tic tac toe ball di SDN Karangtengah III Wonosari Kabupaten Gunungkidul.

Desain penelitian yang digunakan adalah deskriptif kuantitatif karena menggunakan angka-angka untuk mencadarkan karakteristik individu atau kelompok. Hal ini sesuai dengan pendapat (Damaianti, 2011) bahwa penelitian deskriptif kuantitatif merupakan penelitian yang bertujuan menjelaskan fenomena yang ada dengan menggunakan angkaangka untuk mencandarkan karakteristik individu atau kelompok. Penelitian ini dilaksanakan semester 1 tahun pelajaran 2019/2020.

Data dalam penelitian ini dikumpulkan melalui tes dan observasi. Tes digunakan untuk mendapatkan data tentang hasil gerak dasar berlari, melempar, dan menangkap bola yang dilakukan siswa, sedangkan observasi digunakan sebagai teknik untuk mengumpulkan data kebenaran siswa melakukan rangkaian gerak dasar berlari, melempar bola, menangkap bola, dan aktivitas siswa selama pembelajaran.

Teknik analisis data merupakan salah satu cara yang digunakan untuk menganalisis data yang telah diperoleh dalam penelitian. Metode analisis data yang digunakan harus sesuai untuk mencapai hasil yang maksimal. Analisis data dalam penelitian tindakan ini menggunakan analisis data deskriptif kualitatif, sesuai tujuan penelitian ini, maka analisis dilakukan selama maupun setelah proses pengumpulan data. Teknik analisis data yang digunakan meliputi reduksi data, penyajian data, dan verifikasi, (Sugiyono, 2015: 247). 


\section{Hasil dan Pembahasan}

1. Hasil

Permainan tic tac toe ball adalah permainan yang sangat menyenangkan dan dapat dimainkan kapan saja dan dimana saja. Pemain tic tac toe ball harus menguasai beberapa strategi agar dapat memenangkan permainan. Permainan tic tac toe ball ini bentuk lapangannya adalah persegi dengan jumlah kotak di tengahnya ada sembilan. Regu yang dapat menyusun bola plastik tiga buah menjadi satu garis lurus horizontal, vertikal atau diagonal yang menjadi pemenang. Permainan tic tac toe ball ini dibutuhkan kemampuan kecepatan dalam berlari, kecepatan berfikir/ mengambil keputusan, dan kerjasama antara anggota tim.

Pembuatan alat peraga untuk permainan tic tac toe ball ini sangat mudah dan bahan yang digunakan mudah didapatkan. Alat dan bahan pembuatannya bisa menggunakan barang-barang bekas yang sudah tidak terpakai dan harganya murah.

a. Alat dan Bahan

Bahan yang digunakan adalah kertas, tas plastik/tas kresek, tali rafia, kardus, lem, selang air, bambu, pipa air, lakban, dan pasir dan semen. Alat yang digunakan adalah gunting/pisau, penggaris, gergaji, dan ember cat.

\section{b. Cara pembuatan}

Setelah semua alat dan bahan pembuatan tersedia, maka langkahlangkah proses pembuatannya adalah sebagai berikut.

1) Bola kertas

a) Siapkan kertas, tas plastik, tali rafia, dan lakban;

b) Gulung kertas dan diremas-remas/ dipadatkan hingga membentuk bulat seperti bola;

c) Gulungan kertas yang sudah berbentuk bulat, masukan kedalam tas plastik;

d) Gulung tas plastik tadi hingga membentuk bola, sesuaikan ukuran bola dengan kebutuhan; 
e) Ikat dengan tali rafia dan digulung dengan lakban agar bola tadi semakin kuat dan tidak mudah rusak.

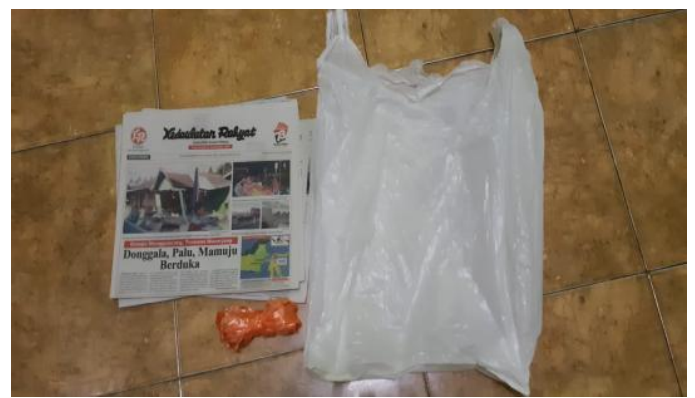

Gambar 2. Bahan pembuatan bola plastik kresek

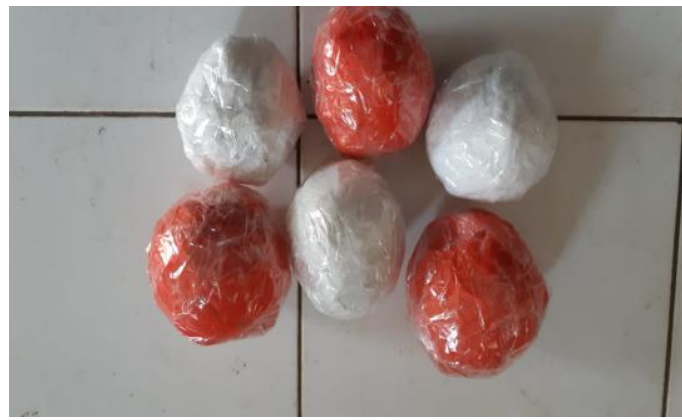

Gambar 3. Hasil pembuatan bola plastik kresek

c. Lapangan permainan tic tac toe ball

1) Siapkan kardus (kardus bekas susu), lem, gunting, dan penggaris;

2) Buka kardus susu dan disambungkan menggunakan lem;

3) Bentuk pola menjadi tiga kolom dan tiga baris;

4) Gunting kardus susu sesuai ukuran permainan tic tac toe ball yang diinginkan.

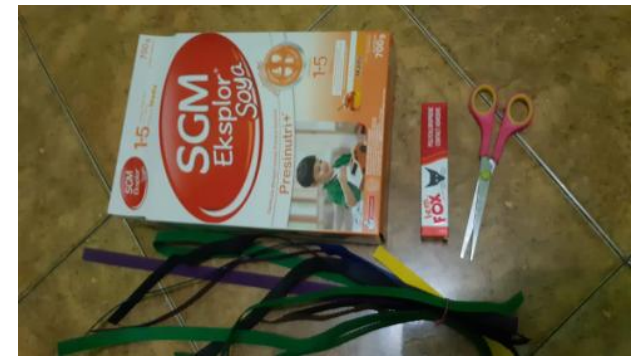

Gambar 4. Bahan pembuatan kotak permainan tic tac toe ball 


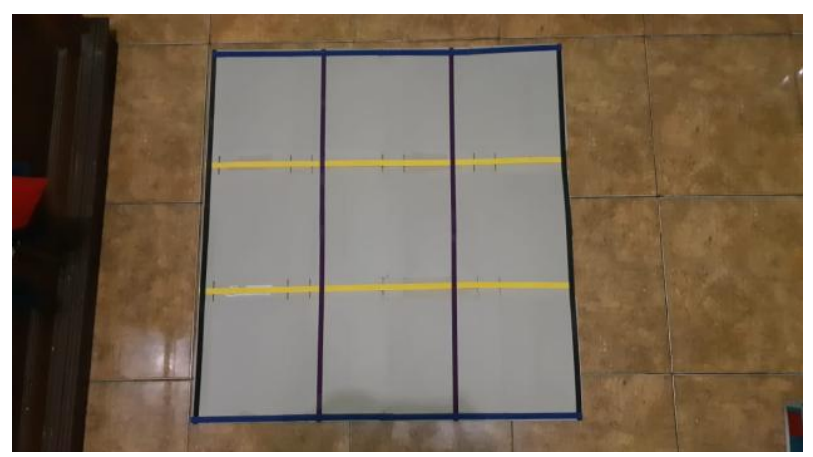

Gambar 5. Hasil pembuatan kotak permainan tic tac toe ball

d. Lingkaran/kolong

1) Siapkan selang air, pipa air, pisau, gergaji, tali rafia, dan lem;

2) Potong selang air dengan ukuran yang disesuaikan dengan kebutuhan;

3) Potong pipa air untuk menyambung selang tadi;

4) Sambung dua ujung selang dengan pipa air dan dilem kemudian ikat dengan tali rafia agar tidak mudah lepas.

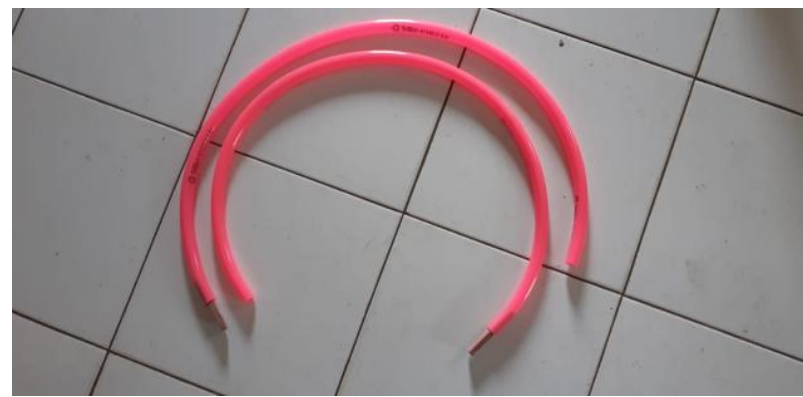

Gambar 6. Bahan pembuatan lingkaran/kolong

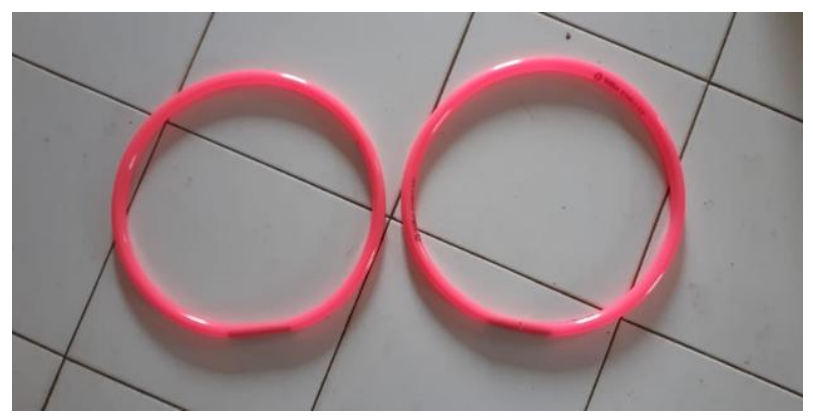

Gambar 7. Hasil pembuatan lingkaran/Kolong 
e. Gawang

1) Siapkan pipa air, pasir, semen, gergaji, lem, dan tali rafia;

2) Potong pipa paralon dengan ukuran yang disesuaikan dengan kebutuhan;

3) Sambung potongan pipa air hingga membentuk gawang;

4) Campurkan pasir dan semen;

5) Masukkan kedua ujung pipa air bagian bawah ke dalam ember cat kemudian masukkan campuran pasir dan semen;

6) Tunggu hingga campuran pasir dan semen mengeras.
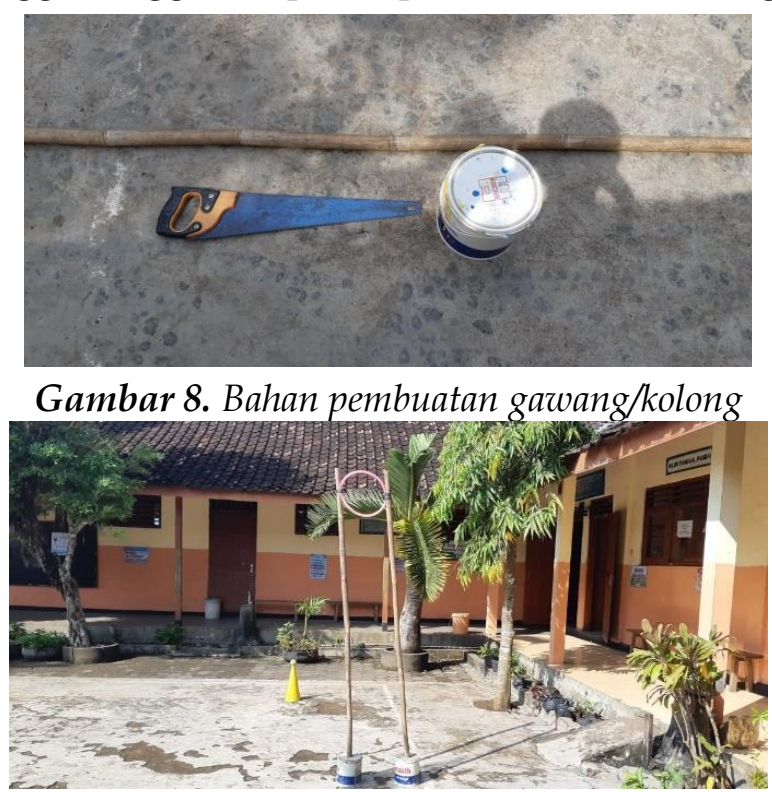

Gambar 9. Hasil pembuatan gawang/kolong

Cara bermain tic tac toe ball sangat mudah dan sederhana, dimainkan oleh dua orang, setiap pemain mendapatkan tiga bola untuk disusun dalam kotak permainan yang berjumlah sembilan kotak. Pemain dikatakan sebagai pemenang apabila dapat menyusun tiga benda/bola tersebut membentuk garis horizontal, vertikal, dan diagonal.

Hasil observasi awal pembelajaran kasti siswa kelas IV SDN Karangtengah III Wonosari Kabupaten Gunungkidul dengan KKM mata pelajaran PJOK adalah 77, bahwa hasil belajar gerak dasar berlari, melempar dan menangkap bola pada permainan kasti siswa kelas IV di 
SDN Karangtengah III sangat rendah. Guru menerapkan pembelajaran permainan bola kecil (kasti) dengan pendekatan permainan tic tac toe ball untuk meningkatkan hasil belajar permainan bola kecil (kasti) di SDN Karangtengah III Wonosari.

\section{Aplikasi Praktis dalam Pembelajaran}

Kombinasi berlari dengan permainan tic tac toe ball

1) Kombinasi melempar dan menangkap dengan permainan tic tac toe ball

Pertemuan pertama, pembelajaran gerak dasar berlari menggunakan permainan tic tac toe ball secara sederhana yang dimodifikasi. Alat yang digunakan bola kresek dan gambar lapangan permainan tic tac toe ball. Siswa dibagi menjadi empat regu, siswa putra dan putri disendirikan agar kemampuan dalam berlari sama rata. Jarak antara siswa dengan lapangan permainan tic tac toe ball dibuat bervariasi. Permainan pertama jarak siswa dengan lapangan permainan tic tac toe ball dibuat 10 meter, permainan kedua jarak 15 meter, dan permainan ketiga dibuat 20 meter. Setiap regu diberi tiga bola kresek. Siswa pertama berlari secepat-cepatnya dengan membawa satu bola kresek untuk ditempatkan atau disusun di lapangan permainan tic tac toe ball. Siswa kedua dan ketiga secara bergantian berlari membawa bola kresek tadi untuk ditempatkan di lapangan permainan tic tac toe ball yang telah disiapkan. Siswa selanjutnya berlari menuju lapangan permainan tic tac toe ball untuk memindahkan satu bola kresek yang telah ditempatkan di lapangan permainan tic tac toe ball oleh siswa sebelumnya hingga membentuk garis lurus horizontal, vertikal, maupun diagonal. Regu dinyatakan sebagai pemenang adalah regu tercepat yang berhasil menyusun bola kresek dilapangan permainan tic tac toe ball membentuk garis lurus horizontal, vertikal, maupun diagonal.

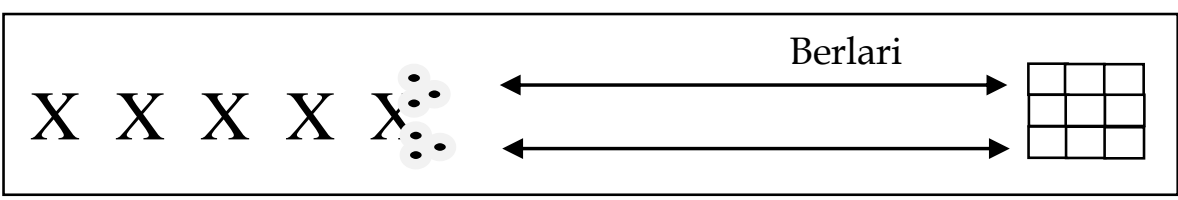

Gambar 11. Rancangan kombinasi berlari dengan permainan tic tac toe ball 
2) Kombinasi lempar tangkap melewati lingkaran dengan permainan tic tac toe ball

Pembelajaran gerak dasar melempar dan menangkap bola dengan kombinasi permainan tic tac toe ball. Alat yang dibutuhkan adalah bola kresek dan lapangan permainan tic tac toe ball. Siswa kembali dibagi menjadi beberapa regu, dipisah antara laki-laki dan perempuan. Regu perempuan bertanding dengan regu perempuan dan regu laki-laki bertanding dengan regu laki-laki. Siswa melakukan lempar tangkap bola dengan jarak yang bervariasi, pertama 10 meter, kedua 15 meter, dan ketiga 20 meter.

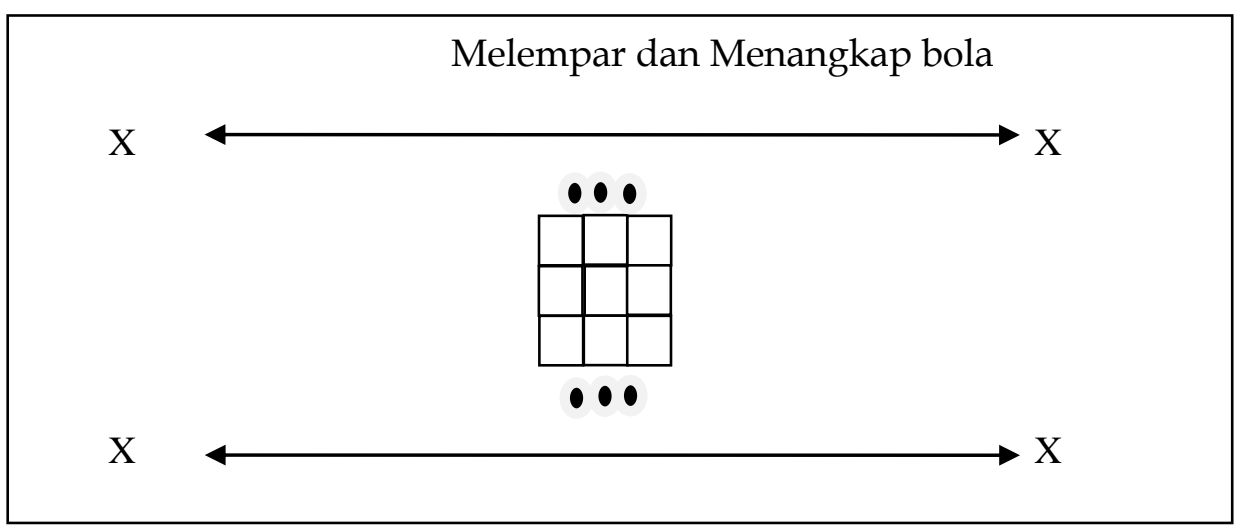

Gambar 12. Rancangan kombinasi lempar tangkap dengan tic tac toe ball

3) Penerapan Teknik dasar berlari, melempar dan menangkap bola kedalam permainan gawang kolong/lingkaran.

Pembelajaran gerak dasar melempar dan menangkap bola menggunakan lingkaran dengan kombinasi permainan tic tac toe ball. Alat yang dibutuhkan adalah lingkaran, bola kresek, lapangan permainan tic tac toe ball dan gawang untuk menggantung kolong. Siswa kembali dibagi menjadi beberapa regu, dipisah antara laki-laki dan perempuan. Siswa melakukan lempar bola melewati kolong dan bola ditangkap oleh teman pasangannya dan kemudian berlari untuk menyusun bola kresek kedalam permainan tic tac toe ball dengan jarak yang bervariasi, pertama 10 meter, kedua 15 meter, dan ketiga 20 meter. 

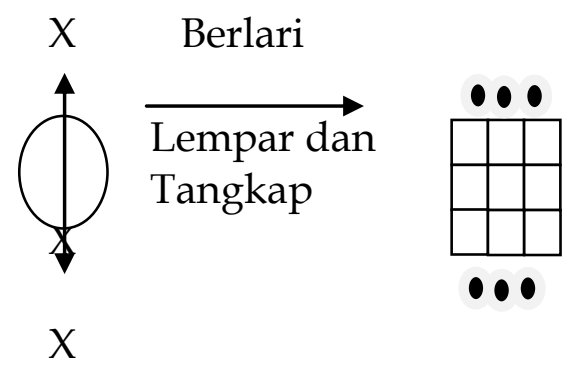

Lempar

Tangkap

Berlari

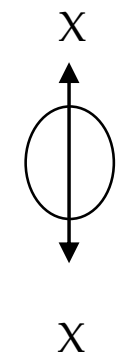

Gambar 13. Rancangan kombinasi lempar tangkap melewati lingkaran dengan permainan tic tac toe ball

4) Penerapan Teknik Dasar Berlari, Melempar, dan Menangkap Bola Kedalam Permainan Kasti

Pertemuan kedua, menerapkan gerak dasar berlari, melempar, dan menangkap bola kedalam permainan gawang kolong/lingkaran. Alat yang digunakan adalah bola plastik kresek satu buah dan dua gawang lingkaran/kolong.

a) Waktu permainan

(1) Lamanya permainan disesuaikan dengan waktu pembelajaran.

(2) Permainan dilaksanakan dalam dua babak.

b) Pemain

(1) Permainan terdiri dari dua regu saling berhadapan.

(2) Jumlah pemain disesuaikan dengan ukuran lapangan.

(3) Pergantian pemain bebas, pemain yang diganti boleh dimasukkan/ dimainkan lagi.

c) Bentuk dan ukuran lapangan.

(1) Ukuran lapangan disesuaikan dengan kondisi lingkungan.

(2) Bentuk lapangan adalah persegi panjang. 

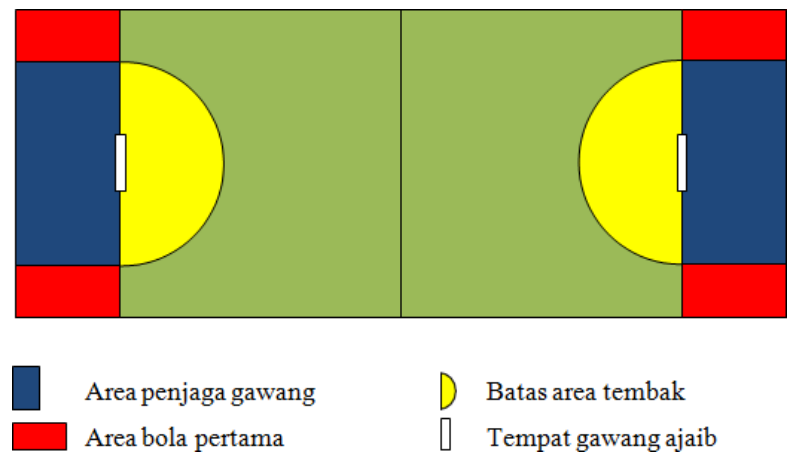

Gambar 14. Lapangan permainan gawang kolong (Prabowo, 2018)

5) Penerapan Teknik Dasar Berlari, Melempar, dan Menangkap Bola Kedalam Permainan Kasti

Menerapkan gerak dasar permainan tic tac toe ball yaitu gerak dasar berlari, melempar bola dengan sasaran dan menangkap bola kedalam permainan kasti. Lapangan kasti terdiri dari beberapa bagian yaitu, pertama bagian untuk pemain yang akan melempar (area pelempar atau pelambung), area pemukul, area pos-pos, dan ruang bebas. Lapangan kasti berbentuk persegi panjang dengan ukuran panjang 60-70 meter dan lebar 30 meter. Peralatan yang digunakan dalam permainan bola kasti, yaitu:

a) bola kasti atau bola tenis,

b) tongkat pemukul,

c) bendera kecil atau keset,

d) tiang hinggap.

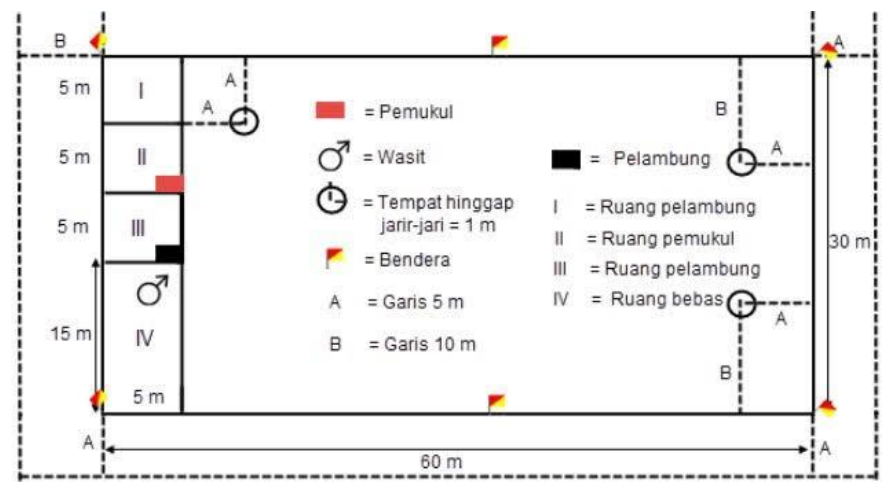

Gambar 15. Lapangan Kasti 


\section{Pembahasan}

Pada saat melakukan permainan bola kecil (kasti), guru melakukan penilaian aktivitas siswa menggunakan lembar observasi. Penilaian unjuk gerak dasar melempar, menangkap bola dan hasil melempar, dan menangkap bola dilakukan pada waktu tersendiri setelah kegiatan pembelajaran selesai.

\section{Hasil Aplikasi Praktis Inovasi Pembelajaran}

Metode pembelajaran meningkatkan kemampuan berlari, melempar bola, dan menangkap bola melalui permainan tic tac toe ball ini digunakan dalam kegiatan belajar mengajar pada mata pelajaran Pendidikan Jasmani Olahraga dan Kesehatan. Indikator keberhasilan dari penerapan permainan tic tac toe ball dalam pembelajaran pendidikan jasmani olahraga dan kesehatan dapat dilihat dari hasil penilaian, baik proses pembelajaran maupun penilaian akhir siswa.

Nilai akhir hasil belajar gerak dasar lempar tangkap siswa diperoleh dari jumlah total nilai yang diperoleh dari tiga aspek setelah dipersentase. Tiga aspek tersebut yaitu unjuk gerak dasar berlari, melempar, menangkap bola, hasil berlari, melempar, menangkap bola dan aktivitas selama pembelajaran, dengan persentase gerak berlari, melempar dan menangkap $40 \%$, hasil lempar tangkap 35\% dan aktivitas selama kegiatan pembelajaran 25\%. Data unjuk gerak dasar lempar tangkap, hasil lempar tangkap dan aktivitas siswa selama pembelajaran dikumpulkan dengan teknik observasi menggunakan lembar observasi.

Berdasarkan hasil observasi awal, tingkat hasil belajar gerak dasar berlari, melempar, dan menangkap bola sangat rendah yaitu dari jumlah siswa kelas IV yaitu 24 anak, hanya enam siswa yang memperoleh nilai diatas $\mathrm{KKM}$ /tuntas, dan 17 anak dikatagorikan belum tuntas. Hal ini dapat dilihat dari tabel observasi awal permainan kasti di bawah ini.

Tabel 1. Hasil Belajar Permainan Bola Kecil (Kasti) Awal

\begin{tabular}{cccccc}
\hline No & $\begin{array}{c}\text { Rentang } \\
\text { Nilai }\end{array}$ & Keterangan & $\begin{array}{c}\text { Jumlah } \\
\text { Anak }\end{array}$ & Persentase & $\begin{array}{c}\text { Jumlah Siswa } \\
\text { Tuntas KKM (77) }\end{array}$ \\
\hline 1 & $86-100$ & Sangat Baik (A) & 0 & $0 \%$ & 6 siswa atau \\
\cline { 2 - 5 }
\end{tabular}




\begin{tabular}{cccccc}
2 & $85-92$ & Baik (B) & 2 & $9 \%$ & $\mathbf{2 6 \%}$ \\
3 & $77-84$ & Cukup (C) & 4 & $17 \%$ & \\
4 & $<77$ & Kurang (D) & 17 & $74 \%$ & \\
\hline \multicolumn{7}{c}{ Jumlah } & $\mathbf{2 3}$ & $\mathbf{1 0 0 \%}$ \\
\hline
\end{tabular}

Siswa kelas IV SDN Karangtengah III Tahun Pelajaran 2019/2020 berjumlah 23 siswa, dalam pembelajaran olahraga materi pembelajaran bola kecil (kasti), meliputi gerak dasar berlari, melempar, dan menangkap bola. Banyak siswa yang belum mampu melakukan gerak dasar melempar dan menangkap bola dengan kontrol yang baik. Pada saat dilaksanakan pembelajaran gerak dasar melempar dan menangkap bola, kebanyakan siswa melempar terlalu jauh/keras, tidak terarah dan tidak tepat sasaran sehingga sulit ditangkap. Saat bermain kasti, siswa terlihat kurang bersemangat dan bekerja sama dalam pelaksanaannya karena belum menguasai gerak dasar berlari, melempar, dan menangkap bola dengan baik. Dari hasil observasi awal, diketahui hanya terdapat enam siswa yang berhasil mencapai nilai KKM 77 atau sejumlah 26\%, dan 17 siswa mendapat nilai < 77 (Kurang/D) atau sejumlah 74\%. Hal ini berarti masih ada $74 \%$ atau 17 siswa yang memperoleh nilai di bawah KKM. Data awal tersebut menunjukkan bahwa pembelajaran bola kecil (kasti) dalam materi hasil belajar gerak dasar berlari, melempar, dan menangkap bola masih sangat rendah.

Permainan tic tac toe ball dapat meningkatkan hasil belajar permainan bola kecil (kasti) dalam hal gerak dasar berlari, melempar, dan menangkap bola karena alat pembelajaran dan bentuk permainan tic tac toe ball dapat digunakan untuk melatih siswa melakukan gerak dasar berlari, melempar, dan menangkap bola dengan kontrol yang baik sehingga hasil lempar tangkapnya menjadi banyak. Hal tersebut sesuai dengan pendapat (Munadi, 2012: 190) bahwa pemilihan alat pembelajaran harus sesuai dengan tujuan pembelajaran atau kompetensi yang ingin dicapai. Permainan tic tac toe ball yang dilakukan secara beregu dan memungkinkan siswa untuk selalu bergerak, sesuai dengan karakter siswa sekolah dasar yang senang bermain, senang bergerak dan senang bekerja dalam kelompok, hal ini sesuai dengan pendapat dengan (Kurniawan, 
2016). Selain itu, peraturan yang mudah dilakukan, membutuhkan kerja sama dan kerja keras untuk memenangkan permainan dapat menanamkan karakter gotong royong (kerjasama), mandiri (kerja keras/ semangat) dan integritas (mematuhi aturan/ sportivitas) kepada siswa.

Setelah pembelajaran dengan permainan tic tac toe ball, siswa sangat antusias dan bersemangat dalam pelaksanaan pembelajaran. Hampir semua siswa aktif dan melaksanakan tugas yang diberikan oleh guru. Saat melakukan gerak dasar lempar tangkap, siswa berusaha mengontrol bola dengan baik. Selain itu, saat melakukan permainan gawang kolong, tampak siswa bekerja sama dengan baik. Dari hasil observasi, dapat dilihat hasilnya sebagai berikut.

Tabel 2. Hasil Belajar Permainan Bola Kecil (Kasti) Akhir

\begin{tabular}{cccccc}
\hline No & $\begin{array}{c}\text { Rentang } \\
\text { Nilai }\end{array}$ & Keterangan & $\begin{array}{c}\text { Jumlah } \\
\text { Anak }\end{array}$ & Persentase & $\begin{array}{c}\text { Jumlah Siswa } \\
\text { Tuntas KKM (77) }\end{array}$ \\
\hline 1 & $86-100$ & Sangat Baik (A) & 5 & $22 \%$ & \\
2 & $85-92$ & Baik (B) & 10 & $43 \%$ & 21 siswa atau \\
3 & $77-84$ & Cukup (C) & 6 & $26 \%$ & $\mathbf{9 1 \%}$ \\
4 & $<77$ & Kurang (D) & 2 & $9 \%$ & \\
\hline \multicolumn{7}{r}{ Jumlah } & $\mathbf{2 3}$ & $\mathbf{1 0 0 \%}$ & \\
\hline
\end{tabular}

Tabel diatas, dapat dilihat setelah dilaksanakan pembelajaran menggunakan tic tac toe ball terdapat 21 siswa yang berhasil mencapai nilai KKM 77 atau sejumlah 91\%, lima siswa mendapat nilai antara 86 s.d. 100 (sangat baik/A) atau sejumlah $22 \%$, sepuluh siswa mendapat nilai antara 85 s.d. 92 (Baik/B) atau sejumlah 43\%, enam siswa mendapatkan nilai antara 77 s.d. 84 (Cukup/C) atau sejumlah 26\%, dan dua siswa mendapat nilai < 77 (Kurang/D) atau sejumlah 9\%. Dari data tersebut, dapat diambil kesimpulan bahwa permainan bola kecil (kasti) setelah dilaksanakan pembelajaran dengan menggunakan permainan tic tac toe ball hasil belajarnya meningkat, meski masih ada dua siswa yang mendapat nilai dibawah KKM.

Menurut Suyono (2015: 85) strategi pembelajaran sebagai serangkaian kegiatan yang berhubungan dengan pengelolan siswa, lingkungan belajar, sumber belajar, dan penilaian guna mencapai tujuan pembelajaran. Permainan tic tac toe ball dapat meningkatkan hasil belajar siswa kelas IV SDN 
Karangtengah III Wonosari. Hal ini dapat kita lihat dari data observasi awal dengan data observasi akhir, terbukti adanya perubahan hasil belajar siswa kelas IV SDN Karangtengah III secara signifikan, akan lebih jelas digambarkan pada grafik hasil pembelajaran permainan bola kecil (kasti) dengan menerapkan permainan tic tac toe ball di bawah ini.

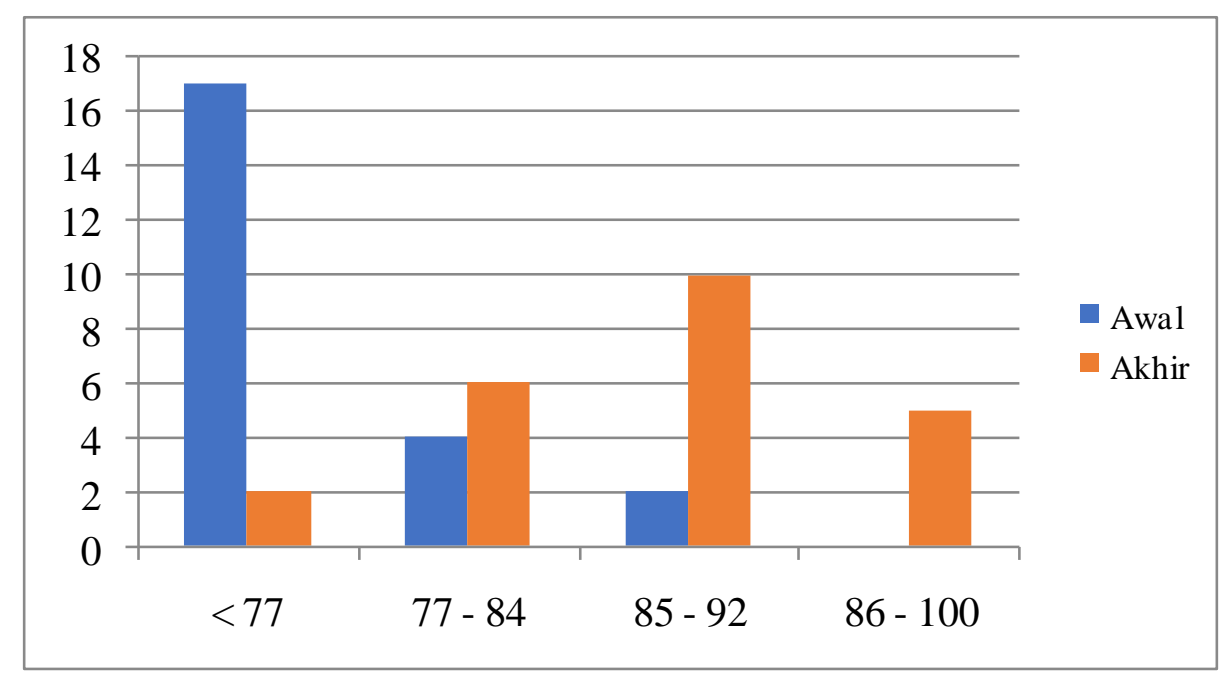

Grafik 1. Hasil Belajar Permainan Kasti

Metode pembelajaran menurut (Kusuma, 2016) mengatakan bahwa metode pembelajaran merupakan suatu cara menerapkan rencana pembelajaran yang telah disusun oleh guru dalam bentuk kegiatan yang nyata dan praktis guna mencapai tujuan pembelajaran. Hasil analisis tersebut dapat dibuktikan bahwa dengan permainan tic tac toe ball dapat meningkatkan hasil belajar permainan bola kecil (kasti) dalam materi gerak dasar berlari, melempar, dan menangkap bola pada siswa kelas IV SDN Karangtengah III tahun pelajaran 2019/2020. Hal ini disebabkan karena permainan tic tac toe ball merupakan bentuk permainan menggunakan gerak dasar berlari, melempar, dan menangkap bola yang sesuai dengan karakter anak sekolah dasar yang senang bermain, senang bergerak, senang bekerja dalam kelompok. Selain itu, permainan tic tac toe ball juga melatih siswa untuk dapat berpikir cepat dan taktis serta menentukan strategi yang baik untuk memenangkan permainan. Dalam permainan tic tac toe ball juga membutuhkan kerja 
sama yang baik agar memenangkan permainan. Permainan tic tac toe ball yang menyenangkan dan peraturan permainan yang mudah dilaksanakan.

\section{Penutup}

Berdasarkan dari hasil data yang diperoleh, dapat disimpulkan bahwa permainan tic tac toe ball dapat meningkatkan hasil belajar siswa kelas IV SDN Karangtengah III Tahun Pelajaran 2019/2020. Hal tersebut ditunjukkan dengan adanya peningkatan kemampuan siswa dalam unjuk gerak dasar lempar tangkap dan peningkatan hasil lempar tangkapnya. Selain itu, siswa bersemangat dan saling bekerja sama selama proses pembelajaran. Siswa yang memperoleh hasil belajar memenuhi nilai KKM (77) pada kondisi awal hanya enam siswa atau sekitar $26 \%$, setelah diterapkan pembelajaran menggunakan inovasi, siswa yang berhasil mencapai KKM (77) meningkat menjadi 21 siswa atau sekitar $91 \%$.

Sesuai dengan simpulan dan dalam rangka meningkatkan pembelajaran Pendidikan Jasmani Olahraga dan Kesehatan (PJOK) di sekolah, maka dapat disampaikan saran kepada sekolah agar lebih meningkatkan kelengkapan alat dan fasilitas yang digunakan dalam pembelajaran PJOK sesuai dengan kebutuhan atau jumlah siswa, sehingga proses pembelajaran dapat berjalan dengan lancar. Kepada Guru PJOK, diharapkan untuk meningkatkan model pembelajaran yang lain atau lebih kreatif dan inovatif agar gerak dasar pada materi permainan bola kecil (kasti) dapat mencapai nilai sesuai KKM yang telah ditetapkan oleh sekolah.

\section{Ucapan Terimakasih}

Penulisan karya ilmiah ini dapat selesai dengan dukungan dan bantuan dari beberapa pihak. Terima kasih penulis ucapkan pada keluarga, kepala sekolah, teman-teman guru dan siswa SDN Karangtengah III. Penulis juga mengucapkan terima kasih kepada Direktur Direktorat Guru dan Tenaga Pendidikan Dasar dan editor jurnal Didaktika Pendidikan Dasar yang telah memberikan bimbingan dan fasilitas dalam penulisan dan penerbitan artikel ini. 


\section{Daftar Referensi}

Damaianti, S. d. (2011). Metode Penelitian Pendidikan Bahasa. Bandung: Remaja Rosdakarya.

Kurniawan, M. (2016). Implementasi Pendidikan Karakter Disiplin dalam Pendidikan Agama Islam di SMA Negeri 1 Batusangkar. Jurnal AlFikrah Volume 4, 2.

Kusuma, E. R. (2016). Menjadi Guru Hebat dengan Hypnoteaching. Jakarta: Kata Pena.

Lumintuarso, R. (2011). Peralatan Olahraga Anak (POA) Untuk Pengembangan Multilateral. Yogyakarta: UNY Press.

Munadi, Y. (2012). Media Pembelajaran. Bandung: Gaung Persada.

Pidarta, M. (2012). Analisis Data Penelitian-Penelitian Kualitatif dan Artikel. Surabaya: Unesa University press.

Prabowo, A. (2018). Permainan Gawang Ajaib untuk Meningkatkan Hasil Belajar Gerak Dasar Lempar Tangkap Siswa Sekolah Dasar. Jurnal Dikdaktika Pendidikan Dasar.

Rahmi, R., Fitriati, F., \& Fachraini, S. (2019). An Analysis of Teachers' Perceptions toward the Role of ICT Based Media in Teaching and Learning Process among Primary Schools' Teachers. Jurnal Ilmiah Peuradeun, 7(3), 469-482. doi:10.26811/peuradeun.v7i3.335

Rusli, Lutan. (1988). Belajar Keterampilan Motorik, Pengantar Teori, dan Metode. Jakarta: Departemen P\&K Dirjen Dikti Proyek Pengembangan Lembaga Pendidikan dan Tenaga Kependidikan.

Slameto. (2010). Belajar dan Faktor yang Memengaruhinya. Jakarta: Rineka Cipta.

Sugiyono. (2015). Metode Penelitian Pendidikan: Pendekatan Kuantitatif, Kualitatif dan RED. Bandung: Alfabeta.

Suyono, H. (2015). Implementasi Belajar dan Pembelajran. Bandung: Remaja Rosdakarya.

Tabrani ZA. (2014). Dasar-Dasar Metodologi Penelitian Kualitatif. Yogyakarta: Darussalam Publishing.

Walidin, W., Idris, S., \& Tabrani ZA. (2015). Metodologi Penelitian Kualitatif $\mathcal{E}$ Grounded Theory. Banda Aceh: FTK Ar-Raniry Press.

Wardani, P. D. (2019, Juni 29). Implementasi Pendidikan Anak Usia Sekolah Dasar. Retrieved from http:// pulungdwiwardani.wordpress.com. 